\title{
Evaluation of fungicidal, bactericidal and anti-tumor activities of lactones of medium and large sizes of cycles obtained from levoglucosenone
}

\author{
C Lily Kh. Faizullina, ${ }^{1+}$ Yulia A. Khalilova, ${ }^{1}$ Artur R. Tagirov, ${ }^{1}$ Yulia S. Galimova, ${ }^{1}$ \\ Alyona S. Ryabova, ${ }^{2}$ Naila F. Galimzyanova, ${ }^{2}$ and Farid A. Valeev ${ }^{1}$ \\ ${ }^{1}$ Ufa Institute of Chemistry of the Russian Academy of Sciences. Oktyabrya Ave., 71. Ufa, 450054. Russia. \\ Phone: +7 (3472) 35-60-66.E-mail: sinvmet@anrb.ru \\ ${ }^{2}$ Ufa Institute of Biology of the Russian Academy of Sciences. Oktyabrya Ave., 71. Ufa, 450054. Russia. \\ Phone:+7 (3472)35-57-04.E-mail:sinvmet@anrb.ru
}

*Supervising author; ${ }^{+}$Corresponding author

Keywords: levoglucosenone, lactones, fungicidal activity, bactericidal activity, antitumor activity.

Abstract
Medium and large lactones attract the attention of chemists by the uniqueness of their structure, versatile biological activity and limited availability. Among the secondary metabolites of this group, $\beta$-lactones are more common, then $\gamma$ - and $\delta$-lactones, classical and non-classical macrolides, polyene antibiotics, spiro-macrolides and macrolactones. On the basis of many lactones, important preparations of the most diverse pharmacological action have been obtained.

Earlier, we proposed a 3-stage scheme for the synthesis of chiral lactones of medium and large size based on levoglucosenone. The lactones obtained according to this scheme contain the carbohydrate residue annelated at the $\beta, \gamma$-positions relative to the hydroxy group. To study the structure-activity relationship, it is necessary to establish the biological role of this carbohydrate residue in reference lactones.

For this purpose, a number of lactones were obtained on the basis of levoglucosenone and their in vitro bioscreening of antifungal, antimicrobial, and antitumor activity was performed.

It was found that the methyl substituent in the $\omega$-position in the lactone and the benzene ring annulated with the lactone cycle exhibit a slight fungistatic activity towards the fungi: Bipolaris sorokiniana, Fusarium oxysporum, Rhizoctonia solani. Macrocyclic lactone and lactone annelated benzene ring showed weak cytotoxic properties against cells of LOX IMVI (melanoma) and A498, UO-31 (kidney cancer).

\section{References}

[1] S. Omura. The Search for bioactive compounds from microorganisms. Springer Verlag, New York. 1992.

[2] T.G. Back. The synthesis of macrocyclic lactones: Approaches to complex macrolide antibiotics. Tetrahedron. 1977. Vol.33. P.3041-3059.

[3] K.C. Nicolaou. Synthesis of macrolides. Tetrahedron. 1977. Vol.33. P.683-710.

[4] M. Petrzilka. A New Method for the Construction of Macrolides Stereoselective Synthesis of ( \pm )Phoracantholide J. Preliminary communication. Helv.Chim.Acta. 1978. Vol.61. P.3075-3078.

[5] G. Drager, A. Kirschning, R. Thiericke, M. Zerlin. Decanolides, 10-membered lactones of natural origin. Natural Product Reports. 1996. P.365-375.

[6] G.R. Pettit, Zb.A. Cichacz, F. Gao, M.R. Boyd, J.M. Schmidt. Isolation and structure of the cancer cell growth inhibitor dictyostatin 1. J. Chem. Soc. Chem. Commun. 1994. P.1111-1112.

[7] B. Bodo, L. Molho, D. Davoust, D. Molho. Fungal macrolides: Structure determination and biosynthesis of achaetolide, a lactone from Achaetomium cristalliferum. Phytochemistry. 1983. Vol.22. P.447-451.

[8] J.F. Rivero-Crus, G. Garcia-Aguirre, C.M. Cerda-Garcia-Rojas, R. Mata. Conformational behavior and absolute stereostructure of two phytotoxic nonenolides from the fungus Phoma herbarum. Tetrahedron. 2000. Vol.56. P.5337-5344.

[9] B.P. Moore, W.V. Brown. The chemistry of the metasternal gland secretion of the eucalypt longicorn Phoracantha synonyma (Coleoptera:Cerambycidae). Aust. J. Chem. 1976. Vol.29. P.1365-1374.

[10] B. Fischer, H. Anke, O. Sterner. Humicolactone, A New Bioactive 10-Membered Lactone from the Fungus Gilmaniella humicola. Nat.Prod.Lett. 1995. Vol.7. P.303-308. 
EVALUATION OF FUNGICIDAL, BACTERICIDAL AND ANTI-TUMOR ACTIVITIES OF LACTONES... $100-105$

[11] A. Göhrt, A. Zeeck, K. Hütter, R. Kirsch, H. Kluge, R. Thiericke. Secondary metabolites by chemical screening. 9 Decarestrictines, a new family of inhibitors of cholesterol biosynthesis from Penicillium. J. Antibiotics. 1992. Vol.45. P.66-73.

[12] A.L. Rogovik, J.P. Chanoine, R.D. Goldman. Pharmacotherapy and weight-loss supplements for treatment of paediatric obesity. Drugs. 2010. Vol.70. P.335-346.

[13] E.S. Istvan, J. Deisenhofer. Structural Mechanism for Statin Inhibition of HMG-CoA Reductase. Science. 2001. Vol.292. P.1160-1164.

[14] E. Rubinstein. Comparative safety of the different macrolides. Int. J. Antimicrob Agents. 2001. Vol.18. P.71-76.

[15] A.W. Thomson. FK-506-How much potential? Immunol. Today. 1989. Vol.10. P.6-10.

[16] E.L. Hazen, R. Brown. Science. 1950. Vol.112. P.2911-2912.

[17] V.V. Belakhov, Yu.D. Shenin. Synthesis and antifungal activity of N-trialkylsilyl derivatives of nystatin. Chemical Pharmaceutical Journal. 2008. Vol.42. No.6. P.15-18. (russian)

[18] S.L. Schreiber. Chemistry and Biology of the Immunophilins and Their Immunosuppressive Ligands. Science. 1991. Vol.251. P.283-287.

[19] W.C. Campbell, M.H. Fisher, E.O. Stapley, G. Albers-Schonberg, T.A. Jacob. Ivermectin: a potent new antiparasitic agent. Science. 1983. Vol.221. P.823-828.

[20] Yu.A. Khalilova, A.R. Tagirov, O.Yu. Doronina, L.V. Spirikhin, Sh.M. Salikhov, F.A. Valeev. Russ. J. Org. Chem. 2014. Vol.50. P.118-124. (russian)

[21] Yu.A. Khalilova, L.V. Spirikhin, Sh.M. Salikhov, F.A. Valeev. Russ. J. Org. Chem. 2014. Vol.50. P.125-135. (russian)

[22] Yu.S. Galimova, A.R. Tagirov, L.Kh. Faizullina, Sh.M. Salikhov, F.A. Valeev. Russ. J. Org. Chem. 2017. Vol.53. P.377-383. DOI:10.1134/S1070428017030113.

[23] L.Kh. Faizullina, Y.A.Khalilova, Sh.M.Salikhov, F.A.Valeev. Stereocontrolled synthesis of (9S)ketodecanolide on the basis of Michael adducts obtained from levoglucosenone and cyclohexanone. Chem. Heterocycl. Compd. 2018. Vol.54. P.598-603.

[24] A.R. Tagirov, L.Kh. Faizullina, Sh.M. Salikhov, F.A. Valeev. Levoglucosenone in the synthesis of chiral benzodecanolide. Butlerov Communications. 2014. Vol.39. No.10. P.48-50. ROI: jbc-02/14-39-10-48

[25] M.C. Alley, D.A. Scudiero, P.A. Monks, M.L. Hursey, M.J. Czerwinski, D.L. Fine, B.J. Abbott, J.G. Mayo, R.H. Shoemaker, M.R. Boyd. Feasibility of drug screening with panels of human tumor cell lines using a microculture tetrazolium assay. Cancer Res. 1988. Vol.48. P.589-601.

[26] M.R. Grever, S.A. Schepartz, B.A. Chabner. The National Cancer Institute: Cancer drug discovery and development program. Seminars in Oncology. 1992. Vol.19. P.622-638.

[27] M.R. Boyd, K.D. Paull. Some practical considerations and applications of the National Cancer Institute in vitro anticancer drug discovery screen. Drug Dev. Res. 1995. Vol.34. P.91-109.

[28] R.H. Shoemaker. The NCI60 human tumour cell line anticancer drug screen. Nature Rev. 2006. Vol.6. P.813-823. 